\title{
English Teachers' Language Attitudes with Different Academic Background
}

\author{
Gisca Irdayana Lubis \\ English Applied Linguistics \\ Postgraduate School \\ Universitas Negeri Medan \\ Medan, Indonesia \\ giscalubis8@gmail.com
}

\author{
Rahmad Husein \\ English Applied Linguistics \\ Postgraduate School \\ Universitas Negeri Medan \\ Medan, Indonesia
}

\author{
I Wy Dirgeyasa \\ English Applied Linguistics \\ Postgraduate School \\ Universitas Negeri Medan \\ Medan, Indonesia
}

\begin{abstract}
Thisstudy is related to the attitude of English language teachers in teaching activities in the classroom viewed based on differences in educational background. The purpose of this research is to find out the attitude of language shown by the English teacher to English in class, how English teachers use English in teaching and also what their matter. This research uses a descriptive qualitative method. The data from this study were analyzed from Miles, HubermanAnd Saldana. Based on the results of data analysis, there are differences in attitudes shown by english teacher that is positive attitude and negative attitude.
\end{abstract}

Keywords -English Teachers;Language Attitude; Academic Background

\section{INTRODUCTION}

Attitude is important to the teacher because it cannot be neatly separated from the teaching and learning process. Attitude is considered as essential factor influecing language performance. Achievement in a target language relies not only on intellectual capacity, but also on the teacher's attitude toward language in teaching activities. Teaching learning should be approached by English teacher as a social and psychological phenomenon rather than as a purely academic one. Believe emotion and behavioural components of attitude deals with the way one behaves and reacts in particular situation.

Teachers' attitude toward teaching English has an effect on their performance. Ustuner stated that one of the nature of the teachers' attitude in teaching activities. Further, Anderson \&Krathwohl mentions that attitude is learned or established predictions to respond. Attitudes are systems or constructs that are composed of four interrelated qualities: affective responses, cognitions, behavioral intentions, and behaviours.

Teachers' attitude focuses on reinforced behavior as the primary factor responsible for attitude development. When a person is persuaded to act in a way that is not congruent with a pre-existing attitude, he or she may change the attitude to reduce dissonance. Affective, cognitive connective examines the relationship between attitude and beliefs and posits that individuals are in an unstable state when their attitude toward an object, event or person and their knowledge about that are inconsistent. The factors which cast influences on the attitude toward English are the skill, experiences, educational background, age and gender. These hold true for teaching profession also. Teacher as speaker and students as listener skill is the consideration of both.As a system, educational institutions have a strong influence in shaping attitudes because they lay the foundation of understanding and moral concepts within the individual.

From the different academic background, they teach in the classroom, they are center of teaching and learning process. English subject has some level difficulties to learn by students in senior high school. Sometimes the teacher mixed the language to teach several materials that they have the difficulties and also when they see their students could not understand the lesson. In this case, a teacher does not use English fully when they are teaching English subject in the classroom, meanwhile, from this research, the researcher wants to analyze the types of English teachers' language attitude with a different academic background in teaching.

\section{DISCUSSIONS}

In conducting a research, theories are needed to explain some concepts or terms applied in the concerned research. Some terms will be used in this study and they need to theoretically explain.

\section{A. Attitude}

Gardner said that attitudes as "the combination of effort plus desire to achieve the goal of learning plus favorable attitudes towards learning the language". Attitude is said by Baker [3] as "a hypothetical construct used to explain the direction and persistence of human behavior'. According to Matsuda ,the construct "attitude" has three components: cognitive, affective, and behavior. The cognitive component 
refers to his/her thoughts, beliefs, and values about the language; the affective component refers to his/her feelings about it, and the behavior component refers to his/her behavioral intention to plan an action.

Practically, Baker states that attitudes as follows:

a. Attitude is cognitive (eg are capable of being thought about) and effective (eg have feelings and emotions attached to them)

b. Attitudes are dimensional rather that bipolar-they varies in degree of favourability /un-favourability.

c. Attitudes predispose a person to act in a certain way, but the relationship, between attitudes and actions, is not a strong one.

d. Attitude is learned not inherited or genetically endowed.

e. Attitudes tend to persist but they can be modified by experience.

\section{B. Attitude Toward Language}

Chalak\&Kassaian) said that "Attitudes toward a particular language might be either positive or negative". Attitude owes its origin to the collective behavior of the members of a social group. It plays a crucial role in the social behavior of an individual as it defines and promotes certain behavior. This quality of attitude can be viewed from various dimensions, and its relation to language can also be measured in many ways. When someone has positive attitudes towards a language, he/she will eager to use the language in daily activity and in all occasions, while "Negative attitudes is lack of loyalty or abandonment of using the language" .

Based on the description above, positive and negative attitudes toward language can be identified through the following indicators.
a. Positive language attitudes indicators:
1. The speakers are loyal the language viability.
2. The speakers are proud and make the language as their identity.
3. The speakers are aware of language use.
b. Negative language attitude indicators:
1. The speakers are not loyal the language viability.
2. The speakers are not proud and do not make the language as their identity.
3. The speakers are not aware of language use.

The relation between the function of attitude towards language can be concluded that (1) people express their attitude through language to get more friends or to avoid something, for instance, they make contact (conversation) with people they like or avoid people that they do not like by keeping silent, (2) people : express their attitude through language to get trust from others, (3) people express their attitude through language to save their ego, (4) people express their attitude through language to show others who they are (their identity).

\section{Component of Language Attitude}

Attitude is generally defined as a hypothetical construct used to explain the direction and persistence of human behavior and it has three distinct aspects; cognitive, affective and connective [3]. The cognitive aspect is related to thoughts and belief, the effective aspect is related to feelings towards the attitude object and the behavioral aspect is related to the behavioral intention and plan of action.

\section{METHODOLOGY}

This research was conducted descriptive qualitatively. The research focuses on the English teachers in Senior High School in KabupatenSimalungun. The subjects are 4 English teachers with a different academic background. The researcher choose 4 respondents because when they teach in class they have a different attitude to make communication with the students in the class. The subjects are English teacher is who delivers English subject and they have been graduated from different University. The first respondent is a post graduated program from UNIMED. The second is a graduate from UMSU. The third respondent is from UNIVA and the last respondent from SETIA BUDI. All informants are of different age, experiences, and character. So the researcher focus on different academic background shows their attitude and also the components of attitude that is reflected toward the English language in teaching activities. The data were the utterances of 4 teachers' language activities when they deliver the material in the classroom. The researcher focus on their attitude toward English to deliver the material from the beginning until the end of the lesson based on the researcher findings use the video and sound recording. The written result contained quotations from data illustrate and substantiate the presentation. The data include observation (recording and transcription), questionnaire and interview. The technique of data analysis apply base on Interactive models technique by Miles, Huberman\& Saldana theory [11] there are main steps to analyze the data, there are 1. Data condensation is a process of selecting data:

a. Selecting: the researcher selects the English teachers' language in teaching activities that show the attitude toward English from the observation and interview.

b. Focusing: the researcher focus on the English teachers' language with a different academic background which has been select and pays attention to the attitude toward English based on the indicators.

c. Simplifying: the researcher simplify the obtain data by separating all English teachers' language attitude in teaching activities into two categorizations of attitude namely positive and negative.

d. Abstracting: the researcher abstract the data which havebeen simplified by looking the language whether the rules have been matched to the simplified data.

e. Transforming the raw data: the researcher transforms the data into data display with the analysis of each English teachers' language use. 
2. Data display is defined as display an organization assembly of information and to the process of organizing data. To draw conclusions from the mass of data, Miles, Huberman and Saldana's suggest that a good display of data, in the form of tables, charts, networks, and other graphical formats is essential.

3. The conclusion was drawn or verification based on the data display. Based on the data display explaining the factors affecting attitude toward English by different academic background.

\section{IV.RESULT AND CONCLUSION}

The research found that there are the different attitude showed by English teacher namely positive and negative attitude in teaching activities. The teacher needs to be aware that everyone has both positive and negative attitudes. If English teachers present their classes in an attractive way, students will adjust themselves to positive attitudes; conversely, they will hold a negative attitude towards English. Positive attitudes and negative attitudes may lead to decreased motivation and in all likelihood, because of decreased input and interaction, to the unsuccessful attainment of proficiency. The relation between the concept of attitude towards language can be concluded that (1) people's attitude towards language has responses of readiness to react in a certain way, it means that people can react as well as their partner in the conversation, (2) people's attitude towards language is learned through their experience and interaction with their environment. The relation between the component of attitude towards language can be conclude that (1) when people believe that a particular language has a benefit to them (2) When people feel like to a variety of languages, they will use it (3) people's belief and feeling towards a particular language will make them react to use the language or to learn it. The three components of language attitudes normally go together but sometimes the third component reacts conversely.

\section{REFERENCES}

[1] Al-Tamimi \& Shuib. 2009. Motivation and Attitude towards learning English. Hadramout University.

[2] Ahmad Gazali. 2012. Pengaruh Latar Belakang Pendidikan dan Pengalaman Mengajar Terhadap Profesionalime Guru SMK Kompetensi Keahlian Teknik Audio-Vidio se Kot Yogyakarta. UNY

[3] Baker, C. 1992. Attitude and Language. Multilingual Maters.

[4] Barley Mak. 2014. Professional Qualifications of Teachers for English for Primary and Secondary Education - A Brief Comparison between Hong Kong and China. A Chinese University of Hongkong.

[5] Bogdan, R.C \& Biklen, S.K. 1992. Qualitative Research for Education (2 ed).

[6] Faramaz. 2016. Teachers' Attitude and Motivation for Using CALL in around the Language Classroom. An International Journal of Linguistics and Language Research.

[7] Hismanonglu. 2015. Does English language teacher education curriculum promote CEFR awareness of prospective EFL teachers? An International Journal Social and Behaviour Sense.

[8] Holmes, J.2001. An Introduction to Linguistics, 2nd ed. Harlow: Pearson Education Limited.
[9] Karthwohl, D.R 1993. Methods of Education and Science Research: an Integrated Approach White Plains. New York: Longman.

[10] Martin. B.L \& Briggs, L.J. 1986. The Cognitive and affective domains: Integration for instruction and research.

[11] Miles, M.B Huberman, A.M \& Saldana, J. 2014. Qualitatuve data analysis.

[12] Roos, R 2015. Language attitude in the second language situation 